\title{
EVALUATION OF MORPHOMETRIC PARAMETERS IN CASE OF LEUCOJUM VERNUM L. FROM THE PERES FOREST IN VELYKA DOBRON WILDLIFE RESERVE, WESTERN UKRAINE
}

\author{
Erzsébet KOHUT ${ }^{1 *}$, Zoltán KOPOR ${ }^{1}$, Béla NAGY ${ }^{1}$, Zsuzsanna CSOMA ${ }^{1}$, István HADNAGY ${ }^{1}$ \\ ${ }^{1}$ Department of Biology and Chemistry, Ferenc Rákóczi II. Transcarpathian Hungarian Institute, Ukraine
}

*Correspondence:

Erzsébet KOHUT

kohut.erzsebet21@gmail.com

Received: 12 December 2019; Accepted: 24 December 2019; Published: 30 December 2019

\begin{abstract}
Leucojum vernum L. (Amaryllidaceae) is a bulbous geophyte from Central Europe known as medicinal and ornamental plant. Native population of this species can be found in the Peres Forest (parcels number 23-24) from Velyka Dobron Wildlife Reserve (Western Ukraine), monitored continuously since 2014. The aim of this study was the morphometric evaluation of the species and the chemistry analysis of the soil in which the species grow. According to our results the length of leaf sheath was the most variable parameter from the evaluated morphometric indicators (number of leaves, maximum leaf length and width, bract length, leaf sheath length, scape length, and bulb diameter). Correlations were found between maximum leaf length and scape length, but also between maximum leaf length and bract length. Soil chemistry analysis showed that the chemical properties of the soil are favorable for the studied plants. The soil $\mathrm{pH}$ was slightly acidic, the humus content and the supply of alkaline hydrolyzed nitrogen were high, and the amount of soluble $\mathrm{P}_{2} \mathrm{O}_{5}$ was moderate. Differences between the territories were found with respect to the soil agrochemical parameters.
\end{abstract}

Keywords: Leucojum vernum L., morphometric analysis, agrochemical indices, population distribution, Velyka Dobron Wildlife Reserve.

\section{Introduction}

According to recent molecular studies, only two species belong to the genus Leucojum (Amaryllidaceae): Leucojum vernum L. and Leucojum aestivum L. (Fig. 1.) (Lledo et al., 2004). Natural populations of both species can be found in the Ukrainian Transcarpathian region. The genus is also medically important because of galanthamine content of the species. Galanthamine is used for the treatment of Alzheimer's disease (Scott and Goa, 2000). As the alkaloid is obtained from natural sources, there is a need for sustained production of the active principle, together with sustained cultivation of the species. The study conducted by Demir (2014) on the use of galanthamine from L. aestivum showed that the cost of producing drugs used to treat Alzheimer's disease is relatively high. Considering the findings of Demir (2014) and also the climate change (IPCC, 2014), it is important to know, monitor and protect the natural populations of L. vernum and $L$. aestivum, and to develop sustainable cultivation of both species, where it is necessary. It is known that plant populations 
respond slowly to changes in the environment, primarily through morphological, physiological, and biochemical responses. The detection of morphological variability within the population allows the identification of species characteristics (which have also taxonomic significance) and makes possible the record of adaptive characters (Кричфалуший and Комендар, 1990).

The object of this study is $L$. vernum (Spring snowflake), a bulbous geophyte from Central Europe. Its natural habitats are present in the following provinces (regions): Lviv,
Zakarpatska, Ivano-Frankivsk and Chernivtsi. In Zakarpatska it can be found from the plain region to the upper forest zone, between elevations of 100-1400 m above sea level (asl). In the IUCN Red List of Threatened Species it appears in the Least Concern (LC) category, while in the Ukrainian Red Book is listed in the Data Deficient (DD) category. The study of $L$. vernum population in Velyka Dobron Wildlife Reserve started in 2014. Currently, 30 distribution areas are known in the Zakarpatska (Transcarpathian) region (Fig. 2.).

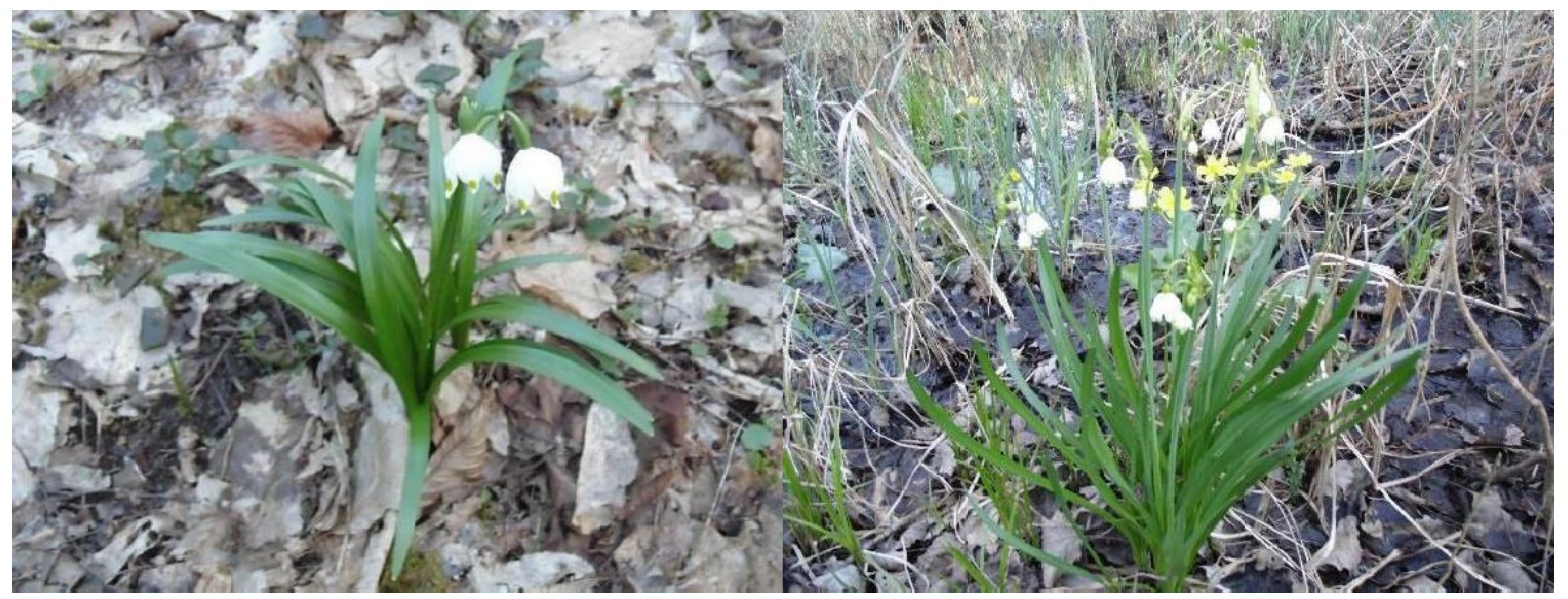

Fig. 1. Leucojum vernum L. and Leucojum aestivum L. from Velyka Dobron Wildlife Reserve (Western Ukraine) (Photos: Erzsébet Kohut)

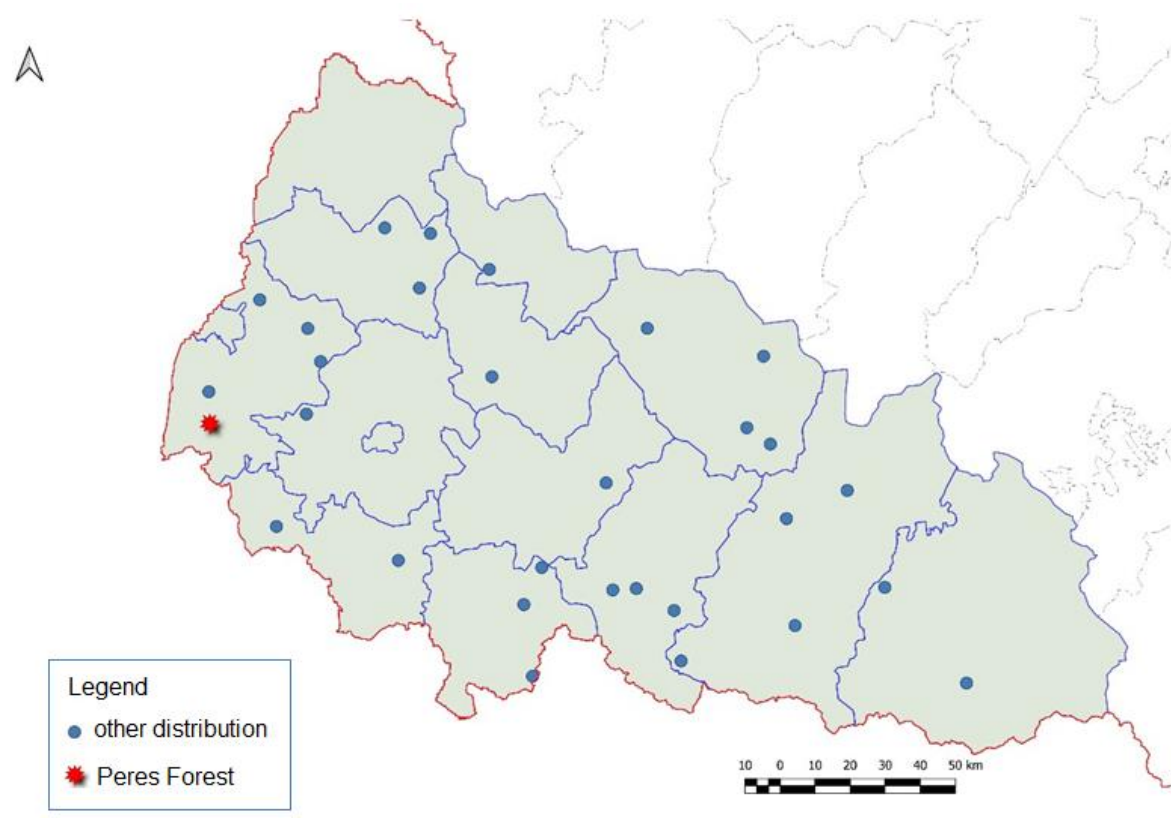

Fig. 2. The distribution of Leucojum vernum L. in the Zakarpatska (Transcarpathian) region 


\section{Materials and Methods}

\subsection{Studied population}

The studied $L$. vernum population is located at $10 \mathrm{~km}$ distance from the ChopZáhony border crossing, in a deciduous floodplain forest with hardwood species (Fraximus excelsior, Quercus robur, Acer platanoides, Populus alba, Populus nigra, Ulmus laevis), on the right bank of the river

Latorica. The three separate territories (were the plants are present) are covering together an area of $238741 \mathrm{~m}^{2}$ (Fig. 3.).

The studied territories along the River Latorica are regularly flooded, and in some years the soil is covered by water for several months, due to the low elevation (110-137 m asl). The density of the species is 75-79 individuals $/ \mathrm{m}^{2}$ (Kohut et al., 2017).

\subsection{Morphometric analysis}

The morphometric data were collected in 2017. In the generative stage of the plants, from each of the 30 quadrates (sampling points), 10 randomly selected individuals were measured (a total of 300 individuals). The following parameters were analyzed: number of leaves $(\mathrm{NL})$, maximum leaf length (MaxLL) and width (MaxLW), bract length (BL), leaf sheath length (LSHL), scape length (SL, from the inferior part of the scape, to the bract), and bulb diameter (BD). BD was measured in case of 60 individuals (2 plants / quadrates). Statistical analysis of the obtained data was performed using Microsoft Excel according to Злобін et al. (2013).

\section{Determination of the linear correlation coefficient}

The simple linear correlation coefficient $(r)$ is used to detect the stochastic relationships (transition between two extremes - fully functional and completely independent) and to express the closeness between two probability variables.

The value of the linear correlation coefficient can vary between +1 and -1 . The positive values of the coefficient indicate a clear relationship between the two variables, while the negative values indicate the opposite relationship. In the case of a function relation, its value is +1 or -1 , and if there is no relationship between the two variables, its value is 0 . A correlation coefficient with a smaller absolute value (near to 0 ), it means also that between the studied parameters there is no relationship (Fidy and Makara, 2005).
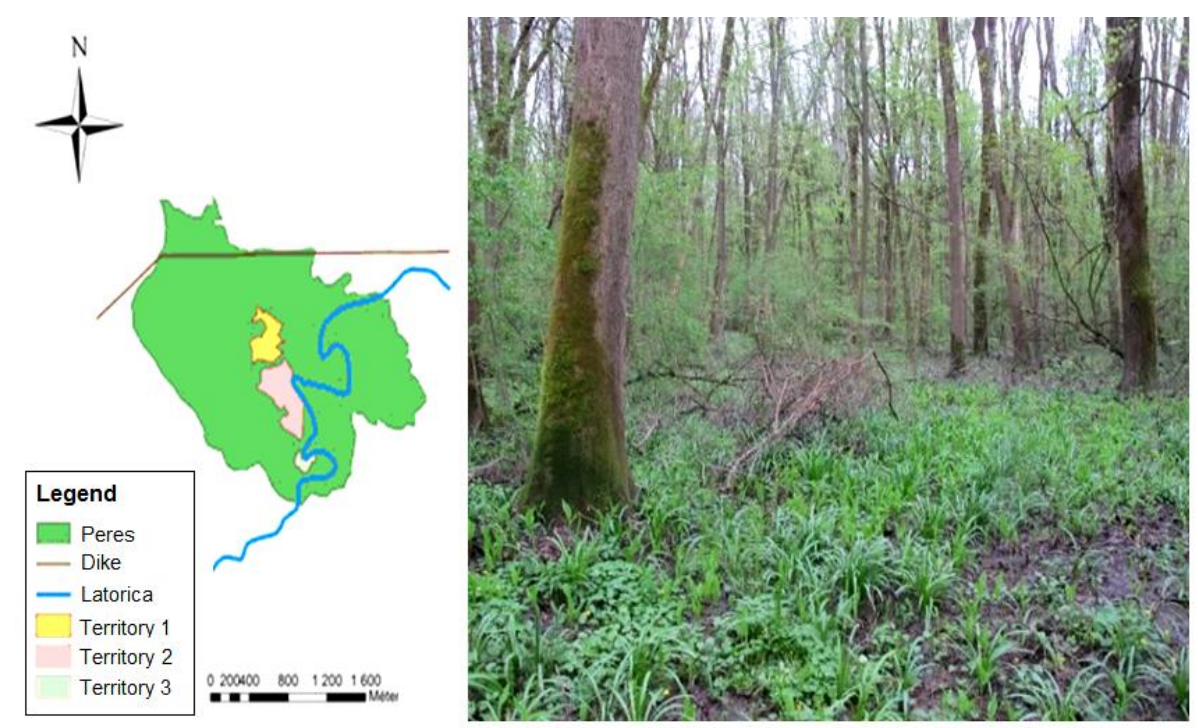

Fig. 3. Leucojum vernum L. population in the Peres Forest from Velyka Dobron Wildlife Reserve (Western Ukraine) (Kohut et al., 2017) 


\section{Significance of the linear correlation} coefficient

The coefficient obtained from the correlation analysis can also be considered as an assumption that there is a relationship between the two variables. Whether this relationship to a specific number $(r)$ is realistic can also be determined by assumption testing. Our null hypothesis in this case is that there is no relationship between the two variables $(r=$ $0)$. The rejection of the null hypothesis depends on the magnitude of the coefficient $(r)$ and the degree of freedom $(f)$ (Fidy and Makara, 2005). Thus, knowing the number of pairs of data $(n)$, the absolute value $(t)$ of the correlation coefficient can be determined for given levels of significance (reliability), above which the null hypothesis can be rejected, i.e. the correlation coefficient (the true relationship between the two variables) can be considered realistic (Péczely, 1998). To test the significance of $r$, a $t$-statistic of $f=n$-2 is used. The formula for $t$-distribution statistics (Fidy and Makara, 2005) is the following (1):

$$
t=\frac{r \sqrt{n-2}}{\sqrt{1-r^{2}}}
$$

\subsection{Soil sampling and chemical analysis}

Samples were collected at a depth of 0-25 $\mathrm{cm}$ after removal of the leaf litter (Fig. 4.). The time of sampling, the number and the coordinates (GPS) of the quadrates (sampling points) were recorded.

In case of each soil sample the following parameters were determined: $\mathrm{pH}$ value, the content in humus, soluble phosphorus and nitrogen. The measurements were carried out in the Laboratory of Soil Science and Agrochemistry of the Ferenc Rákóczi II. Transcarpathian Hungarian Institute.

F-tests and two-sample Student's $t$-tests on the soil data were carried out using Microsoft Excel's Analysis ToolPak. An acceptance level of $p=0.05$ was used in both cases.

\section{Working protocols}

The soil samples were dried at room temperature. After grinding, the samples were passed through a $2 \mathrm{~mm}$ sieve. The $\mathrm{pH}$ of the soils was measured in aqueous and $1 \mathrm{~mol} / \mathrm{dm}^{3}$ $\mathrm{KCl}$ extract with a soil: solvent ratio of 1: 2.5 (ДСТУ ISO 10390:2007).

The soluble phosphorus content of the soils was measured in $0.2 \mathrm{~mol} / \mathrm{dm}^{3} \mathrm{HCl}$ extract according to the Kirsanov method. The soil: solvent ratio was of $1: 5$. After shaking for 1 minute and resting for 15 minutes, the suspension was filtered through a paper filter and the filtrate was analyzed (ДСТУ 4405:2005).

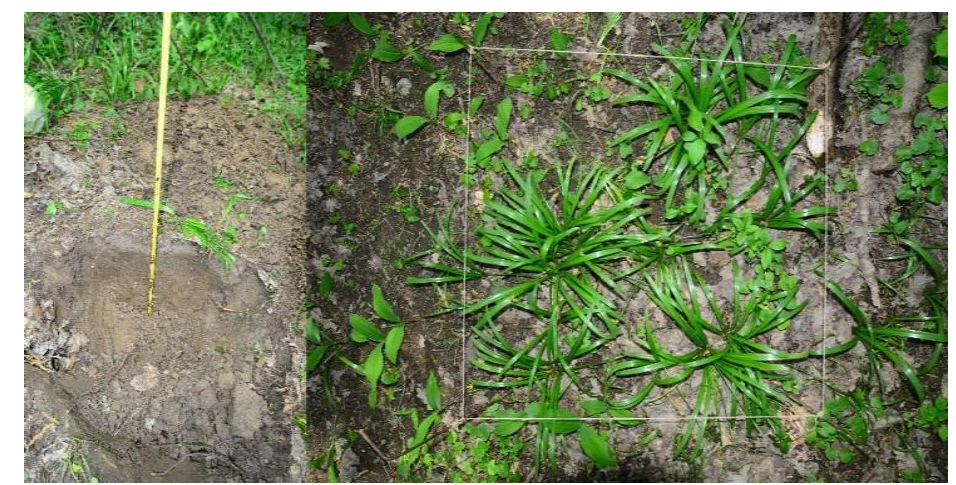

Fig. 4. Soil sampling from the studied quadrates with Leucojum vernum L. in Peres Forest from Velyka Dobron Wildlife Reserve (Western Ukraine) (Photos: Erzsébet Kohut) 
The Tyurin method was used to determine the humus content. In properly prepared soil, the humus is oxidized with potassium dichromate in a highly sulfuric medium. The remaining potassium dichromate is titrated with Mohr's salt solution (ДСТУ 4289:2004).

The values determined during the tests were compared with the accepted values in Ukraine.

The $\mathrm{pH}$ value was measured on a WTW Multi 9620 IDS instrument and the phosphorus content was determined on a Libra S21 spectrophotometer.

The alkaline hydrolyzing nitrogen content of the samples was determined from $1.0 \mathrm{~mol} /$ $\mathrm{dm}^{3} \mathrm{NaOH}$ extract using the Kornfield method. The soil: $\mathrm{NaOH}$ solution ratio was of $1: 2.5$.
The samples were kept in a thermostat for 48 hours at $28^{\circ} \mathrm{C}$ with sodium hydroxide, and then the ammonium absorbed with boric acid was titrated with sulfuric acid (ДСТУ 4405:2005).

\section{Results and discussions}

\subsection{Morphometric analysis}

The The seeds of the harvested capsules (Fig. 5.) were weighed on an analytical balance. The weight of one thousand seeds was equal with $16.19 \mathrm{~g}$. The data used for the morphogram (Fig. 6) are summarized in Table 1.

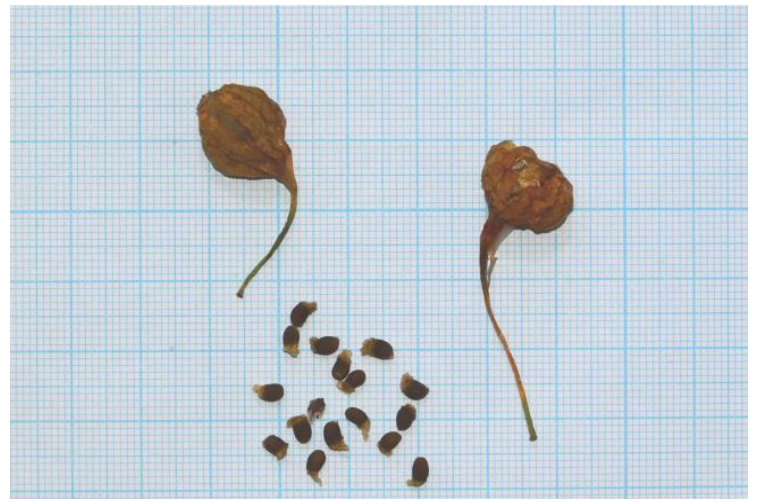

Fig. 5. Capsules and seeds of Leucojum vernum L. from Peres Forest, Velyka Dobron Wildlife Reserve (Western Ukraine) (Photo: Erzsébet Kohut)

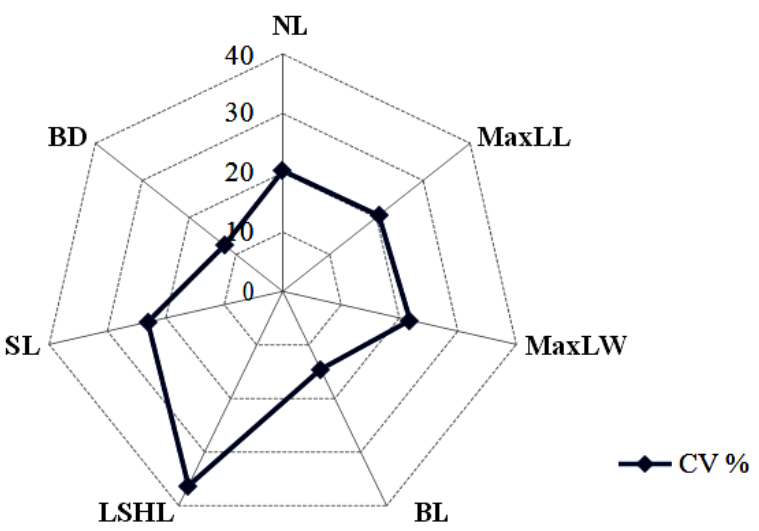

Fig. 6. The morphogram of Leucojum vernum L. collected from Peres Forest, Velyka Dobron Wildlife Reserve (Western Ukraine): NL-number of leaves; MaxLL-maximum leaf length; MaxLW-maximum leaf width; BL-bracts length; LSHL-Leaf sheath length; SL-scape length; BD-bulb diameter 
The coefficient of variation (CV) ranged from $12.5 \%$ to $36.3 \%$ (Fig. 6.). The most variable parameter was the leaf sheath length (CV $=36.3 \%, C V \geq 26 \%$ - high), and the other parameters were found to be less or moderately variable $(\mathrm{CV} \leq 15 \%$ - low, $16 \leq \mathrm{CV} \leq 25 \% \quad-$ moderate). The least variable parameter was the bulb diameter, with a $\mathrm{CV}$ of $12.5 \%$. The results obtained in this study, regarding the morphometric parameters, were similar with those published by Ljubinyec (Любинець) (2013) from Yavorivskyi National Park (Ukrainian Roztocze). In their three years study (2006, 2007 and 2011) the most variable parameter was also the length of the leaf sheath with a CV of $24.6 \%, 19.1 \%$ and $25.8 \%$, respectively.

\subsection{Comparison of morphometric parameters}

Relationships between the 7 studied morphometric parameters were analyzed. For this, a linear correlation test was performed. The examined 300 individuals were collected from 30 quadrates (10 plants/quadrates). In the sampling quadrates, the measured values of each parameters were averaged, so for the comparison, 30 data pairs $(n=30)$ were obtained for each parameter. The obtained values of the coefficient ( $r$ ) from the correlation analysis are summarized in Table 2. Our null hypothesis was that there is no real relationship between two compared variables (no morphometric parameter affects the other). Confidence (significance) of the decision was fixed at 5\% $(p=0.05)$ acceptance level. Pairing the indicators, a total of 21 cases were examined. Of these, in 7 cases significant correlations were found. The strongest significant linear relationship was found between MaxLL and BL $(r=0.765)$ and MaxLL and SL ( $r=0.908)$ (Fig. 7 and 8).

The coefficient of determination for MaxLL and BL is $R^{2}=0.585$ (Fig. 7.) and for MaxLL and SL it is $R^{2}=0.824$ (Fig. 8.). Thus, $58.5 \%$ of the total variation in the maximum leaf length is due to the linear relationship with the bract length, and $82.4 \%$ with the scape length, while the remaining $41.5 \%$ and $17.6 \%$ are other factors, for example random variation or measurement error.

Table 1. Statistical values of the examined morphometric parameters in case of Leucojum vernum L. collected in Peres Forest, Velyka Dobron Wildlife Reserve (Western Ukraine)

\begin{tabular}{|l|l|l|l|l|l|}
\hline Evaluated parameters & $\overline{\boldsymbol{x}}$ & $\boldsymbol{\sigma}$ & SE & $\overline{\boldsymbol{x}}+\mathbf{S E}$ & CV (\%) \\
\hline NL & 4.3 & 0.9 & 0.1 & $4.3 \pm 0.1$ & 20.4 \\
\hline MaxLL (cm) & 32.1 & 6.6 & 0.4 & $32.1 \pm 0.4$ & 20.6 \\
\hline MaxLW(cm) & 15.4 & 3.4 & 0.2 & $15.4 \pm 0.2$ & 21.8 \\
\hline BL (cm) & 38.6 & 5.6 & 0.3 & $38.6 \pm 0.3$ & 14.6 \\
\hline LSHL (cm) & 27.2 & 9.9 & 0.6 & $27.2 \pm 0.6$ & 36.3 \\
\hline SL $(\mathrm{cm})$ & 24.3 & 5.6 & 0.3 & $24.3 \pm 0.3$ & 23.3 \\
\hline BL $(\mathrm{cm})$ & 20.3 & 2.5 & 0.3 & $20.3 \pm 0.3$ & 12.5 \\
\hline
\end{tabular}

Note: NL-number of leaves; MaxLL-maximum leaf length; MaxLW-maximum leaf width; BL-bracts length; LSHL-Leaf sheath length; SL-scape length; BD-bulb diameter 
Table 2. Statistical values of the examined morphometric parameters in case of Leucojum vernum L. collected in Peres Forest, Velyka Dobron Wildlife Reserve (Western Ukraine)

\begin{tabular}{|l|l|l|l|l|l|l|l|}
\hline $\begin{array}{l}\text { Evaluated } \\
\text { parameters }\end{array}$ & NL & $\begin{array}{l}\text { MaxLL } \\
(\mathrm{cm})\end{array}$ & $\begin{array}{l}\text { MaxLW } \\
(\mathrm{cm})\end{array}$ & $\begin{array}{l}\mathrm{BL} \\
(\mathrm{cm})\end{array}$ & $\begin{array}{l}\text { LSHL } \\
(\mathrm{cm})\end{array}$ & $\begin{array}{l}\text { SL } \\
(\mathrm{cm})\end{array}$ & $\begin{array}{l}\text { BD } \\
(\mathrm{cm})\end{array}$ \\
\hline NL & & $\mathbf{0 . 4 9 7}$ & 0.419 & 0.368 & 0.179 & 0.425 & 0.061 \\
\hline MaxLL $(\mathrm{cm})$ & & & $\mathbf{0 . 6 0 4}$ & $\mathbf{0 . 7 6 5}$ & 0.158 & $\mathbf{0 . 9 0 8}$ & 0.181 \\
\hline MaxLW $(\mathrm{cm})$ & & & & $\mathbf{0 . 5 1 3}$ & 0.020 & $\mathbf{0 . 5 1 7}$ & 0.132 \\
\hline BL $(\mathrm{cm})$ & & & & & 0.044 & $\mathbf{0 . 7 3 2}$ & 0.134 \\
\hline LSHL $(\mathrm{cm})$ & & & & & & 0.067 & 0.007 \\
\hline SL $(\mathrm{cm})$ & & & & & & & 0.180 \\
\hline BD $(\mathrm{cm})$ & & & & & & & \\
\hline
\end{tabular}

Note: NL-number of leaves; MaxLL-maximum leaf length; MaxLW-maximum leaf width; BL-bracts length; LSHL-Leaf sheath length; SL-scape length; BD-bulb diameter

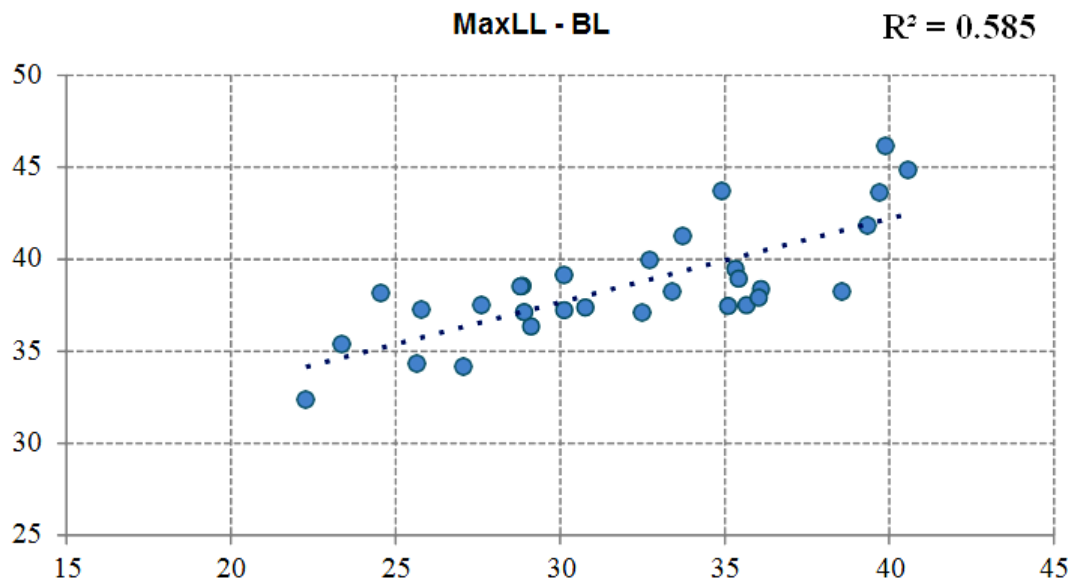

Fig. 7. Correlation between maximum leaf length (MaxLL) and bract length (BL) of Leucojum vernum L. collected from Peres Forest, Velyka Dobron Wildlife Reserve (Western Ukraine)

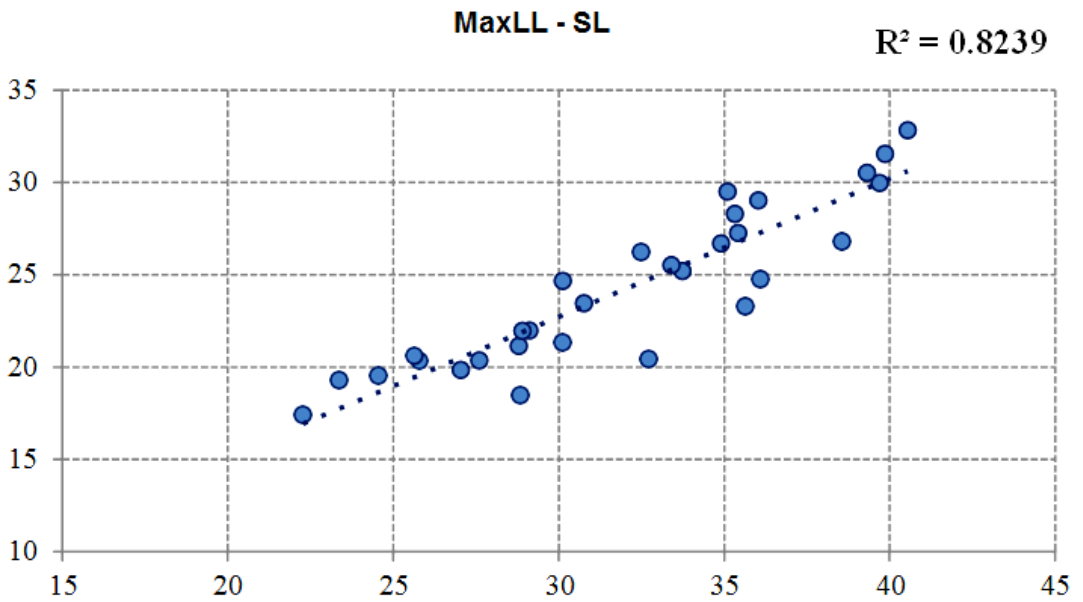

Fig. 8. Correlation between maximum leaf length (MaxLL) and scape length (SL) of Leucojum vernum L. collected from Peres Forest, Velyka Dobron Wildlife Reserve (Western Ukraine) 


\subsection{Soil chemical analysis}

Initially, to analyze the chemical properties of the soil samples we divided the samples into two groups. The first group contained the samples from Territory 1 (T1), while the second group consisted of the samples of Territory 2 and Territory 3 (T2+T3).

The reasoning behind this classification was that $\mathrm{T} 2$ and $\mathrm{T} 3$ are spatially much closer to the Latorica River, hence the soil of these two territories might have different chemical properties as a result of the enhanced influence of the river. Moreover, the samples were taken in an approximate equidistant fashion to ensure a uniform sampling over the whole investigated territory, which inherently led fewer samples from $\mathrm{T} 3$ than $\mathrm{T} 1$ or $\mathrm{T} 2$ due to the smaller area of T3. Thus, separate analysis and comparison of the three regions would have provided much less reliable statistical data.

The following agrochemical parameters were measured on the two groups of samples: the alkaline hydrolyzing nitrogen content, $\mathrm{pH}$ with two methods, soluble $\mathrm{P}_{2} \mathrm{O}_{5}$ content and the humus content (Table 3).

After the evaluation of the measurements the data were analyzed with two-sample
Student's $t$-tests to determine if there are significant differences between the sample means of the two groups, with respect to the agrochemical parameters. Beforehand, F-tests were used to validate if the variance of the two groups are equal regarding the different parameters (acceptance level was $\mathrm{p}=0.05$ ), which is a prerequisite to carry out two-sample Student's $t$-tests. The results of the F-tests showed that the variances are in fact the same with respect to the measured properties so Student's $t$-tests were applied (Table 3). From the results it can be seen, that there are significant differences between the means in four of the five measured parameters. Especially high differences can be identified in the alkaline hydrolyzing nitrogen content (312.05 vs. 240.80 which both represent very good nitrogen supply) and soluble $\mathrm{P}_{2} \mathrm{O}_{5}$ content (58.67 vs. 101.19 representing a medium supply). Besides the potential impact of the Latorica River, this can also be reasoned by the different altitude, age and density of the forests between the two territories, which gives us the opportunity for a future research in the subject.

Table 3. The agrochemical indices of the examined soil samples from Peres Forest, Velyka Dobron Wildlife Reserve (Western Ukraine)

\begin{tabular}{|l|c|c|c|c|c|c|c|}
\hline Indices & $\begin{array}{c}\text { Studied } \\
\text { territory }\end{array}$ & Mean & $\begin{array}{c}\text { Standard } \\
\text { dev. }\end{array}$ & $\begin{array}{c}\text { Sample } \\
\text { size }\end{array}$ & $\mathbf{p}$ (F-test) & $\mathbf{p}$ (t-test) & Significant? \\
\hline $\begin{array}{l}\text { Alkaline } \\
\text { hydrolyzing } \\
\text { nitrogen } \\
(\mathbf{m g} / \mathbf{k g})\end{array}$ & $\mathrm{T} 1$ & 312.05 & 29.34 & 15 & 0.435665 & 0.000001 & YES \\
\cline { 2 - 8 } & $\mathrm{T} 2+\mathrm{T} 3$ & 240.8 & 30.64 & 14 & & & \\
\hline \multirow{2}{*}{$\mathbf{p H}\left(\mathbf{H}_{\mathbf{2}} \mathbf{O}\right)$} & $\mathrm{T} 1$ & 6.33 & 0.25 & 15 & 0.10409 & 0.002347 & YES \\
\cline { 2 - 9 } & $\mathrm{T} 2+\mathrm{T} 3$ & 6.6 & 0.17 & 14 & & & \\
\hline \multirow{2}{*}{$\mathbf{p H}(\mathbf{K C l})$} & $\mathrm{T} 1$ & 5.44 & 0.16 & 15 & 0.198592 & 0.007075 & YES \\
\cline { 2 - 9 } & $\mathrm{T} 2+\mathrm{T} 3$ & 5.64 & 0.2 & 14 & & & YES \\
\hline \multirow{2}{*}{$\begin{array}{l}\text { Soluble } \mathbf{P}_{2} \mathbf{O}_{5} \\
(\mathbf{m g} / \mathbf{~ k g})\end{array}$} & $\mathrm{T} 1$ & 58.67 & 22.87 & 15 & 0.464275 & 0.000035 & \\
\cline { 2 - 9 } & $\mathrm{T} 2+\mathrm{T} 3$ & 101.19 & 23.4 & 14 & & & NO \\
\hline \multirow{2}{*}{$\begin{array}{l}\text { Humus } \\
\text { content }(\%)\end{array}$} & $\mathrm{T} 1$ & 6.15 & 1.19 & 15 & 0.06613 & 0.087411 & \\
\cline { 2 - 9 } & $\mathrm{T} 2+\mathrm{T} 3$ & 5.48 & 0.78 & 14 & & & \\
\hline
\end{tabular}


The mean values of $\mathrm{pH}$ in the aqueous solution were 6.33 and 6.60 for the two groups and 5.44 and 5.64 in the $\mathrm{KCl}$ extract. Thus, in all cases the soil has a slightly acidic or near neutral $\mathrm{pH}$, which is generally favorable for the nutrient uptake of plants. The humus content was the only parameter which didn't show significant difference between the two groups and both of them considered to be good according to the limits of Ukraine.

\section{Conclusions}

According to morphometric results, the most variable parameter was the length of the leaf sheath and the less variable was the bulb diameter, which is the same as reported in the literature of Ljubinyec (Любинець) in 2013. The correlation analysis showed that there is a strong positive relationship between the maximum leaf length and the bract length, and also between the maximum leaf length and

scape length. One thousand seeds weighted $16.19 \mathrm{~g}$. The alluvial type soil had significant accumulation of organic matter and high level of humus content. The soil $\mathrm{pH}$ values (obtained with both methods) are favorable for the growing and development of plants. The soil is of medium supply based on the amount of soluble $\mathrm{P}_{2} \mathrm{O}_{5}$, while alkaline hydrolyzing nitrogen has a high supply. However, there are significant differences between the agrochemical parameters of Territory 1 and Territory 2, 3 (except the humus content), which can be explained by multiple factors and hence will be the subject of a future research.

\section{Conflict of Interest}

The authors declare that the research was conducted in the absence of any commercial or financial relationships that could be construed as a potential conflict of interest.

\section{Acknowledgments}

We appreciate the work of our colleagues from the Department of Biology and Chemistry of Ferenc Rákóczi II. Transcarpathian Hungarian Institute: Krisztina Molnár, Ferenc Molnár, Tibor Ljubka, Gabriella Takács, Fülöp Máté.

We also thank to Erzsébet Domokos and Gergely Kohut for their contributions to the paper.

\section{References}

1. Demir A (2014) Medical Resource Value Appraisal for Leucojum aestivum in Turkey. American Journal of Alzheimer's Disease \& Other Dementias 29(5):448-451. doi.org/10.1177/1533317514535334

2. IPCC (2014) Climate Change 2014: Synthesis Report. Contribution of Working Groups I, II and III to the Fifth Assessment Report of the Intergovernmental Panel on Climate Change [Core Writing Team, R.K. Pachauri and L.A. Meyer (eds.)]. IPCC, Geneva, Switzerland.

https://www.met.hu/downloads.php?fn=/me tadmin/attach/2018/07/bf121478e6e4bb976 886646893cd71ff-ipcc-jelentes-2014.pdf. Accessed 01 Dec 2019

3. Fidy J, Makara G (2005) Biostatisztika, InforMed Kiadó, Budapest

4. Kohut E, Höhn M, Fülöp M, Kopor Z, Ljubka T, Molnár F, Takács G (2017) Előzetes eredmények a Leucojum vernum L. populációjának állapotáról a Peresben. II. RF KMF - Limes 4:9-22.

5. Lledo DM, Davis AP, Crespo MB, Chase MW \& Fay MF (2004) Phylogenetic analysis of Leucojum and Galanthus (Amaryllidaceae) based on plastid matK and nuclear ribosomae spacer (ITS) DNA sequences and morphology. Plant 
Systematics and Evolution 246(3):223-243. doi: 10.1007/s00606-004-0152-0

6. Péczely Gy (1998) Éghajlattan. Nemzeti Tankönyvkiadó, Budapest

7. Scott LJ, Goa KL (2000) Galantamine: a review of its use in Alzheimer's disease. PubMed. 60(5):1095-1122. doi: 10.2165/00003495-200060050-00008

8. Зайцев ГН (1973) Методика биометрических расчетов. Математическая статистика в экспериментальной ботанике. Наука, Москва

9. Злобин ЮА, Скляр ВГ, Клименко АА (2013) Популяции редких видов растений: теоретические основы и методика изучения. Монография. Університетська книга, Суми

10. Кричфалуший ВВ, Комендар ВИ (1990) Биоекология редких видов растений. Свит, Львов

11. Любинець I (2013) Стан і динамічні тенденції ценопопуляції Leucojum vernum L. на території Яворівського національного природного парку. Вісник Львівського університету. Серія біологічна, 63:51-61.

12. http://publications.lnu.edu.ua/bulletins/inde x.php/biology/article/download/8236/8191

13. ДСТУ ISO 10390:2007 Якість грунту. Визначення $\mathrm{pH}$

14. ДСТУ 4289:2004 Якість грунту. Методи визначання органічної речовини

15. ДСТУ 4362:2004 Якість грунту. Показники родючості грунтів

16. ДСТУ 4405:2005 Якість грунту. Визначання рухомих сполук фосфору i калію за методом Кірсанова в модифікації ННЦ ІГА 